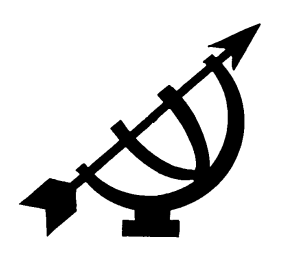

\title{
Beginsels en metodes vir die bepaling van die ouderdom van hominied fossiele en hulle vindplekke
}

\author{
W.J. van Aardt
}

Skool vir Omgewingswetenskappe en Ontwikkeling

Potchefstroomkampus

Noordwes-Universiteit

POTCHEFSTROOM

E-pos: Willie.vanaardt@nwu.ac.za

\begin{abstract}
Principles and methods used for the determination of the age of hominid fossils and their discovery sites

Paleoanthropologists have an array of physical dating methods developed by researchers in the physical sciences. These techniques permit students of hominid evolution and associated culture to have increasing confidence that the evidence of past hominid morphology as expressed by the fossil finds is being placed in the correct chronological order. This article explains in a simple and straightforward way the evidence and logic that have led scientists to conclude that hominid fossils are not a few thousand years but at least several million years old. The main focus is on the ${ }^{40} \mathrm{Ar} /{ }^{39} \mathrm{Ar}$ technique, but other absolute dating techniques such as carbon-14, uranium-thorium-lead and radiocalcium are also reviewed. Relative dating methods are briefly discussed together with paleomagnetism (geomagnetism), optic stimulated luminescence and amino acids.
\end{abstract}

\section{Opsomming}

Beginsels en metodes vir die bepaling van die ouderdom van hominied-fossiele en hulle vindplekke

Paleoantropoloë beskik tans oor 'n verskeidenheid fisiese dateringsmetodes wat deur fisici ontwikkel is. Met hierdie tegnieke kan navorsers van hominied-evolusie en verwante kultuur met toenemende vertroue die fossiel-morfologie van hominiede in die regte chronologiese volgorde plaas. Die 
inhoud van hierdie artikel verklaar in eenvoudige terme, die bewyse en logika wat wetenskaplikes tot die slotsom laat kom het dat fossiele nie slegs 'n paar duisend jaar oud is nie maar wel miljoene jare oud is. Die hooffokus was op die ${ }^{40} \mathrm{Ar} /{ }^{39} \mathrm{Ar}$-dateringsmetode, maar ander absolute dateringstegnieke soos koolstof-14, uraan-thorium-lood en radiokalsium is ook bespreek. Relatiewe dateringsmetodes is kortliks bespreek, tesame met paleomagnetisme (geomagnetisme), opties gestimuleerde luminesensie en aminosure.

\section{Inleiding}

Die ouderdomsbepaling van fossiele is 'n gespesialiseerde studieterrein wat deur 'n span ervare wetenskaplikes met hoogs gesofistikeerde apparaat en berekenings uitgevoer word. 'n Kenmerk van die paleoantroplogie as studieterrein is dat slegs die resultate oor die fossiele se ouderdom neergeskryf word, omdat dateringstegnieke en gepaardgaande berekeninge te ingewikkeld is om dit kortliks te beskryf. By baie Christengelowiges is dit moeilik om te begryp en te aanvaar dat fossiele baie meer as 'n paar duisend jaar oud is. Hierdie artikel is 'n poging om, in 'n verstaanbare taal, voorbeelde van berekenings en figure só voor te stel dat dateringsmetings en berekenings verstaan kan word. Dit laat ruimte sodat die leser, deur sy eie gevolgtrekkings te maak, kan besluit hoe oud 'n fossiel behoort te wees.

Die ouderdom van 'n paleoantropologiese vindplek en die geassosieerde fossielreste van die vroeëre sogenaamde protomense of hominiede moet eers vasgestel word alvorens 'n chronologiese beskrywing gegee kan word van wanneer en hoe die hominiede moontlik ontstaan en ontwikkel het tot die mens (Homo sapiens sapiens). Hoewel dierlike fossiele soos die dinosaurisse 65 miljoen jaar en ouer is, sal met hierdie artikel die aandag bepaal word by opgrawings wat nie ouer as 5 miljoen jaar is nie. Die rede hiervoor is dat, soos in die titel aangedui word, veral aandag gegee sal word aan hominiede of mensagtige fossiele wat in Afrika opgegrawe is. Hierdie fossiele is gewoonlik nie ouer as 4 tot 6 miljoen jaar nie.

Verskeie metodes is beskikbaar om die ouderdom van die sediment waarin 'n fossiel begrawe lê, of die fossiel self, te bepaal. Afhangend van die ouderdom van die vindplek, kan meer as een metode gebruik word. Datering word deur paleoantropoloë en geochronoloë in twee breë kategorieë ingedeel, naamlik relatiewe- en absolute ouderdomsdatering. 


\section{Relatiewe ouderdomsdatering}

Relatiewe dateringsmetodes kom daarop neer dat 'n gegewe fossiel, klipgereedskap of die mineraal van 'n horison waarin die fossiel voorkom, vergelyk word met 'n ander vindplek om vas te stel of dit ouer of jonger is. Met die relatiewe metode kan nie bepaal word wat die presiese ouderdom van die fossiel of vindplek is nie. In die negentiende eeu was die opeenvolging van strata van sedimente van onder na bo byvoorbeeld 'n aanduiding dat die boonste lae jonger moet wees as die onderstes, mits daar nie 'n geologiese versteuring van die lae plaasgevind het nie. 'n Ander tegniek wat tans nog toegepas word, is om die verskillende vindplekke se fossiele anatomies met mekaar te vergelyk. Hierdie tegniek maak 'n studie van alle fossielereste van die diersoorte in die betrokke laag. As die plant- en dierfossiele in 'n bepaalde biostrata, gewoonlik op spesiesvlak, ooreenstem met die biostrata van 'n ander vindplek, duisende kilometers verder, word aanvaar dat die ouderdom van die twee vindplekke dieselfde moet wees.

As die fossiele in 'n bepaalde horison gedurende hulle evolusionêre geskiedenis duidelike veranderings ondergaan het en ook herhaal word by ' $n$ ander horison met dieselfde tipes dierefossiele, behoort hulle ook aan dieselfde tydperk. Diere soos knaagdiere, olifante, antelope en varksoorte is bruikbaar as biologiese merkers van die tyd in fossielvindplekke in Afrika en elders.

Radiometriese datering (met die moontlike uitsondering van radiokalsium) kan nie toegepas word op die fossielryke kalksteengrotte van Swartkrans, Kromdraai en Sterkfontein in Suid Afrika nie. Die rede is dat hierdie grotte nie radiogeniese gesteentes, veral kalium, vir absolute datering besit nie. Die studie van die biostratografie van 'n vindplek en sy geassosieerde fauna help egter om 'n tydstelsel van kontrole en balans in te voer om die ouderdom van die meer tegniese, radiometriese metodes te verifieer. Meer as 64 soogdierspesies, asook voëls (534 fossielreste) reptiele (189 reste) en amfibiërs (107 reste) wat die groter tipe werweldiere uitmaak, is byvoorbeeld by Swartkrans geïdentifiseer. Dit is gedoen van 19078 fossielbeenfragmente wat oor 'n periode van sewe jaar daar opgegrawe is (Watson,1993:37).

Hoewel relatiewe ouderdomsdatering nie presies die ouderdom van 'n fossiel kan bepaal soos absolute dateringsmetodes nie, het dit egter gehelp om 'n verkeerde ouderdomsbepaling deur 'n bepaalde radiometriese metode uit te wys. By 'n vergelykende analise van 'n tand van 'n uitgestorwe varksoort het dit daartoe gelei dat 'n 
dateringsfout ingesluip het in die K-Ar-datering van die KBS Tuff horison by Koobi Fora in Kenia. Dit het gelei tot die hersiening van die ouderdom van 'n homonied fossiel KNM-ER 1470 met meer as ' $n$ halfmiljoen jaar. Sedertdien verkies paleoantropoloë die ${ }^{39} \mathrm{Ar}-/$ ${ }^{40} \mathrm{Ar}$-metode bo die K-Ar-metode in Oos-Afrika, omdat dit as 'n dateringsmetode, noukeuriger is (Leakey et al., 1995:569).

Die herwinning van fossiele by vindplekke van vroeëre homoniede is 'n wetenskap op homself. Sodra 'n hominiedfragment herken word, moet 'n bepaalde protokol gevolg word. Fotografiese- en videoopnames van die presiese vindplek moet gedoen word voordat die eksemplaar verwyder mag word. 'n Lokaliteitsnommer word toegeken en 'n beskrywing van die omgewing se geologie, stratigrafie en paleo-ekologie word gemaak. As met verdere ondersoek gevind word dat daar ' $n$ vars breuk op die eksemplaar is, word die gebied afgekamp en deeglik met siwwe ondersoek, nadat 'n rooster in meter-eenhede op die perseel afgebaken is. 'n Driedimensionele prent word later van die vindplek gemaak en rekenaarmatig gestoor. Die tipe matriks van 'n bepaalde gesteente wat aan die eksemplaar vassit, word opgeskryf en later geanaliseer. Die matriks is gewoonlik 'n aanduiding uit watter geologiese horison of laag die fossiel afkomstig is (Johanson \& Edgar, 1996:67). Ouderdomsbepaling van veral hominiedfossiele word selde gemaak deur 'n gedeelte van die fossiel daarvoor op te offer. Die sediment of die matriks waarin die fossiel hom bevind word daarvoor gebruik. Een rede hiervoor is dat die fossiele wat gevind word uiters skaars en waardevol is en bewaar word vir verdere toekomstige wetenskaplike ondersoeke.

\section{Absolute dateringsmetodes}

Hierdie metodes van ouderdomsbepaling van fossiele is baie meer presies in vergelyking met die relatiewe metodes. Die meeste van die metodes is radiometries en berus op die konstante vervaltempo van sekere radioisotope in gesteentes wat as tydklokke optree en in staat is om, na metings en berekenings, ' $n$ bepaalde ouderdom aan te dui.

\subsection{Radiometriese metodes}

Van die 339 isotope van 84 elemente wat in die natuur voorkom, is 269 stabiel, terwyl 70 radioaktief is. Van hierdie 70 radioaktiewe isotope besit 18 lang halveertye, het oorleef en bly radioaktiwiteit uitstraal sedert die elemente van die sonnestelsel geskep is. Hierdie langlewende radioaktiewe nukliede vorm die basis vir radiometriese datering. Die oorblywende 52 radioaktiewe isotope of radionukliedes 
besit kort halveertye, maar word gedurig geskep deur kernreaksies in die natuur of deur die verval van langlewende radioisotope. Radioaktiewe koolstof $\left({ }^{14} \mathrm{C}\right)$ word byvoorbeeld gedurig gevorm van ${ }^{14} \mathrm{~N}$ (stikstof) in die boonste dele van die atmosfeer deur reaksie met kosmiese straalneutrone (vgl. Figuur 1). Ook word ${ }^{234}$ Th (thorium) verkry deur die verval van ${ }^{238}$ uraan en verval ${ }^{234}$ Th na ${ }^{234} \mathrm{~Pa}$ (proaktinium), ensovoorts.

Bykomstig by die 339 natuurlik voorkomende radionukliedes of radioisotope, is meer as 1650 radioisotope van die elemente wat in die laboratoriums geskep word deur kernreaktore en deeltjieversnellers. Hierdie radioisotope word soms kunsmatige radionukliedes genoem, maar niks daarvan is kunsmatig nie. Hulle bestaan wel nie in die natuur nie, maar bloot omdat hulle kort halveertye het. Genoeg tyd het sedert die elemente van die sonnestelsel geskep is, verloop, sodat hierdie kunsmatige radionukliedes met tyd eenvoudig deur verval tot niet gegaan het. Dit word later aangetoon dat juis die bestaan van radionukliedes met lang halveertye en die afwesigheid van radionukliedes met kort halveertye in die aardkors, 'n semi-kwantitatiewe aanduiding van die hoë ouderdom van die elemente in ons sonnestelsel is.

Radioaktiewe verval kan as 'n statistiese proses verstaan word, waarby elke atoom van 'n gegewe radionuklied presies dieselfde kans het om in 'n bepaalde tydsduur te verval as enige ander atoom van daardie radionuklied. Hierdie karakteristieke waarskynlikheid is bekend as die vervalkonstante, $\lambda$, en word uitgedruk as die waarskynlikheid per tydseenheid. Vervalkonstantes strek van nul vir 'n stabiele nuklied tot 1,0 vir 'n radionuklied wat onmiddellik verval. Indien 'n mens byvoorbeeld aanneem dat in 'n houertjie 100 atome van 'n radioisotoop met 'n vervalkonstante van 0,1 jaar $(10 \%$ per jaar) is, kan ons dus verwag dat 10 van die atome verval aan die einde van die eerste jaar, 9 (10\% van die oorblywende 90$)$ aan die einde van die die tweede jaar, 8,1 (10\% van die oorblewende 81$)$ aan die einde van die derde jaar, ensovoorts.

Die vergelyking wat die statistiese beginsel uitdruk wat radioaktiwiteit beheers, is:

$$
\mathrm{P}_{\mathrm{t}}=\mathrm{P}_{0} \mathrm{e}^{-\lambda \mathrm{t}} \quad \text { (Vergelyking (1)) }
$$

waar $\mathrm{P}_{0}$ die aantal moederatome is by begintyd $0 ; \mathrm{P}$ is die aantal moederatome by ' $n$ bepaalde latere tyd $t$, en $\lambda$ is die vervalkonstante. 
Hierdie vergelyking vorm die basis van alle radiometriese dateringsmetodes.

Omdat verval 'n statistiese proses is, is dit nie moontlik om presies te sê wanneer 'n bepaalde atoom gaan verval nie. Vir 'n klein aantal atome is dit byna onmootlik om die juiste aantal vervalle in ' $n$ gegewe tyd te bepaal. In die geval van die 100 atome in die houertjie, mag 13 wel in die eerste jaar verval, 6 in die tweede jaar en 8 in die derde jaar, ensovoorts. Vir 'n groot aantal atome word die statistiese onsekerheid egter verwaarloosbaar klein en die vergelyking hierbo kan gebruik word om baie presies die aantal atome wat in 'n bepaalde tyd verval, te bepaal. Gelukkig is die aantal atome in 'n baie klein massa materie groot. So byvoorbeeld bevat 0,000 01 gram kalium 150000 triljoen atome!

Die vraag kan gevra word hoe die vervalkonstante van 'n baie lang lewende radionuklied bepaal word. As dit nie noukeurig gemeet kan word nie, sal groot uitwykings van die ouderdom plaasvind. Die eerste stap in die meetproses is om die moederradionuklied so suiwer as moontlik te verkry. Dit kan gedoen word met onder andere chemiese skeidings- en ander suiweringsprosesse. Dan word byvoorbeeld een gram kalium (wat die radionuklied ${ }^{40} \mathrm{~K}$ bevat) baie noukeurig afgeweeg met 'n ultrapresisie massabalans. Die radioaktiwitiet van die een gram kalium word vervolgens gemeet. Daar is gevind dat die een gram $\mathrm{K}, 31,58$ disintegrasies per sekonde afgee. (Disintegrasies beteken nie dat die kern disintegreer nie, maar dat slegs 31,58 energiepakkies per sekonde in die vorm van 'n deeltjie uit die K-kerne van die 1 gram kalium vrykom.) Elke pakkie kan deur 'n sintillasieteller gesien en getel word. Vir een gram kalium word dus 99,6 $\times 10^{7}$ disintegrasies per jaar verkry. Ook moet bereken word wat die totale aantal kaliumatome in een gram kalium is: dit is $0,15415 \times 10^{23}$ atome en word bereken met behulp van Avogrado se getal $\left(6,0225 \times 10^{23}\right)$.

Die presiese hoeveelhede nukliedes en radionukliedes vanaf die moeder en stabiele nukliedes van die dogter, word sedert die vyftigerjare nie meer deur massabalanse nie, maar deur noukeriger massaspektrometers in ' $n$ vakuum gedoen. Omdat elkeen van die drie isotope van byvoorbeeld kalium $\left({ }^{39} \mathrm{~K},{ }^{40} \mathrm{~K},{ }^{41} \mathrm{~K}\right)$ se massa met een proton verskil, kan 'n massaspektrometer die isotope skei in 'n sterk magneetveld in 'n vakuum. Die massaspektrometer kan ook alle ander atome wat nie kalium is nie, onderskei en dit nie tel nie. Die hoeveelhede kalium-39 en argon-40 per atoom kan getel word indien die K-Ar-metode gebruik word. Vir die ${ }^{39} \mathrm{Ar} /{ }^{40} \mathrm{Ar}$-metode moet 
die atoomhoeveelhede van ${ }^{36} \mathrm{Ar},{ }^{37} \mathrm{Ar},{ }^{38} \mathrm{Ar},{ }^{39} \mathrm{Ar}$ en ${ }^{40} \mathrm{Ar}$ ook deur die massaspektrometer gemeet word.

$$
\begin{aligned}
& \text { Vervalkonstante } \lambda=\frac{d n}{d t} \frac{A Y}{f N_{0}} \\
& \text { waar } \frac{d n}{d t}=\text { disintegrasies per sekonde per gram kalium is, } \\
& A=\text { atoommassa van kalium } \\
& f=\text { atoomvoorkoms van }{ }^{40} \text { kalium in die kaliummonster } \\
& \left.N_{0}=0,0001167\right) \\
& Y=\text { avogrado se getal }\left(6,0225 \times 10^{23}\right) \\
& \text { As die berekenings gedoen word: } \\
& Y=31,58 \times \frac{39,0983 \times 3,1558 \times 10^{7}}{0,0001167 \times 6,0225 \times 10^{23}} \\
& Y=5,81 \times 10^{-11} \text { per jaar wat die vervalkonstante vir }{ }^{40} \mathrm{~K} \text { is. }
\end{aligned}
$$

Die meeste mense is bekend met die term halveertyd, $t_{1 / 2}$, ' $n$ ander konstante van 'n radionuklied. Die halveertyd is die tyd wat nodig is om presies die helfte van enige hoeveelheid van die moederradionuklied te laat verval. Soos verwag, is die halveertyd verwant aan die vervalkonstante. Hierdie verwantskap kan gevind word deur te stel dat $P_{t}$ gelyk is aan een halwe van $P_{0}$ en die vergelyking hierbo op te los vir $t$.

Die resultaat is dan die volgende:

$$
t_{1 / 2}=\frac{\log _{\mathrm{e}} 2}{\mathrm{Y}}
$$

Die halveertyd van die hipotetiese radionuklied hierbo, wat 100 atome in die houertjie het, met 'n verval konstante van $0,1 \mathrm{j}^{-1}$, kan vervolgens bepaal word:

$$
t_{1 / 2}=\frac{0,693}{0,1 j^{-1}}=6,93 \mathrm{j}
$$

Dit beteken 'n mens kan verwag dat elke 6,93 jaar die helfte van die oorblewende atome van die ouerlike radio-nuklied sal verval en dat 'n ooreenstemmende aantal dogteratome sal verskyn. Dus bly $50 \%$ 
van die ouerlike radionukliede oor aan die einde van 6,93 jaar, $25 \%$ aan die einde van 13,86 jaar, $12,5 \%$ aan die einde van 20,79 jaar, ensovoorts. As die persentasies van die moeder-en dogter-radionukliede grafies voorgestel word as 'n funksie van die aantal verloopte halfveringstyd, is die resultaat twee eksponensiële krommes. Die een wys die afname van die ouer aan en die ander een die toename van die dogter. As nie een van die ouer- of dogteratome uit die stelsel ontsnap nie, sal die som van die twee krommes (ouer en dogter) altyd gelyk wees aan die oorspronklike hoeveelheid van die moeder-radionuklied. 'n Ander interessante eienskap van eksponensiële verval is dat vir 'n baie groot aantal atome, en lang halveertye, die ouer radionuklied prakties "nooit" verdwyn nie.

Die halveertye van meer as 1700 bekende radionuklides strek van 'n fraksie van 'n sekonde tot biljoene jare. Die halveertye en vervalkonstantes van die radioisotope wat vir radiometriese datering gebruik word, word in Tabel 1 aangetoon.

Tabel 1: Die belangrikste moeder- en dogterisotope wat gebruik word om die ouderdom van gesteentes en ouer fossiele te bepaal

\begin{tabular}{|c|c|c|c|}
\hline $\begin{array}{l}\text { Moeder- } \\
\text { radio-isotoop } \\
\text { (radioaktief) }\end{array}$ & $\begin{array}{c}\text { Dogterisotoop } \\
\text { (nie radioaktief, } \\
\text { stabiel) }\end{array}$ & $\begin{array}{l}\text { Halveertyd } \\
\text { (miljoen jare) }\end{array}$ & $\begin{array}{c}\text { Vervalkonstante } \\
\text { (per jaar) }\end{array}$ \\
\hline${ }^{40}$ Kalium & ${ }^{40} \mathrm{Ar}$ & 1250 & $5,81 \times 10^{-11}$ \\
\hline${ }^{87}$ Rubidium & ${ }^{87} \mathrm{Sr}$ & 48800 & $1,42 \times 10^{-11}$ \\
\hline${ }^{147}$ Samarium & ${ }^{143} \mathrm{Nd}$ & 106000 & $6,54 \times 10^{-12}$ \\
\hline${ }^{176}$ Lutesium & ${ }^{176} \mathrm{Hf}$ & 35900 & $1,93 \times 10^{-11}$ \\
\hline${ }^{187}$ Renium & ${ }^{187}$ Os & 43000 & $1,612 \times 10^{-11}$ \\
\hline${ }^{232}$ Torium & ${ }^{208} \mathrm{~Pb}$ & 14000 & $4,948 \times 10^{-11}$ \\
\hline${ }^{235}$ Uraan & ${ }^{207} \mathrm{~Pb}$ & 704 & $9,8485 \times 10^{-10}$ \\
\hline${ }^{238}$ Uraan & ${ }^{206} \mathrm{~Pb}$ & 4470 & $1,55125 \times 10^{-10}$ \\
\hline
\end{tabular}

Vergelyking (1) is nie prakties vir die gebruik van radiometriese datering nie, omdat daar nie ' $n$ manier is om die oorspronklike 
hoeveelheid van die moeder, $\mathrm{P}_{0}$, vas te stel nie. Gelukkig is daar ' $\mathrm{n}$ maklike oplossing vir hierdie probleem, omdat die som van die moederatome wat oor is en die atome van die dogteratome wat gevorm het altyd gelyk moet wees met die oorspronklike moederatome.

$$
\mathrm{P}_{0}=\mathrm{P}_{t}+\mathrm{D}_{t}
$$

Vervang nou $\mathrm{P}_{t}=\mathrm{D}_{t}$ vir $\mathrm{P}_{0}$ in vergelyking (1) dan is:

$$
\begin{aligned}
& P_{t}=\left(P_{t}+D_{t}\right) \mathrm{e}^{-v t} \\
& \text { en } \mathrm{D}_{t}=\mathrm{P}_{t}\left(\mathrm{e}^{\mathrm{\gamma t}}-1\right) .
\end{aligned}
$$

Hierdie vergelyking kan opgelos word vir $t$, (ouderdom van die mineraal):

$$
t=\frac{1}{\mathrm{~V}} \log _{\mathrm{e}} \frac{\left(\underline{\mathrm{D}}_{t}+1\right)}{\mathrm{P}_{t}^{-}}
$$

Hierdie vergelyking vorm die basis vir radiometriese ouderdomsdatering as die dogterisotoop nie reeds teenwoordig is tydens die vorming van die gesteente nie.

As die gesteente of mineraal waarvan die ouderdom bepaal moet word alreeds die dogterisotoop tydens die vorming bevat, moet die hoeveelheid van die dogter $\left(D_{0}\right)$ eers afgetrek word van die totale gemete hoeveelheid $\left(D_{t}\right)$ voordat die vergelyking toegepas word om die ouderdom vas te stel.

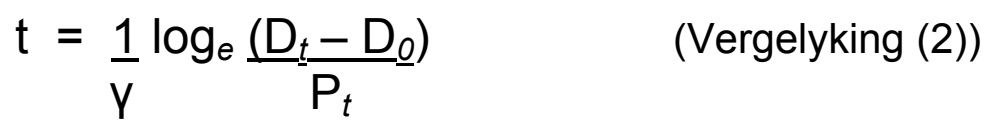

As eerste aanname, kan beweer word dat dit byna onmoontlik is om $D_{0}$ vas te stel om 'n akkurate ouderdomsbepaling te doen. Vir die belangrikste metodes is $D_{0}$ egter óf nul, verwaarloosbaar klein, óf is $\mathrm{D}_{0}$ nie nodig in die berekening nie.

Die vraag kan gevra word of die vervaltempo van 'n radionuklied konstant is. Hierdie moontlikheid is deur Emery (1972:201) en Hopke (1974:513) ondersoek en deur Dalrymple (1991:89) opgesom. Volgens hierdie navorsers, soos blyk uit hulle teoretiese én eksperimentele gegewens, is die kanse dat $\alpha, \beta^{-}$, en e.v. (elektronvangs) vervalkoerse verander, uiters skaars. As dit gebeur is dit ook uitsonderlik klein. Die grootste waargenome veranderinge van $0,18 \%$ vir ${ }^{7}$ berillium sal 'n verwaarloosbare effek vir die berekende radiometriese ouderdom inhou. Dit is belangrik om te 
weet dat geen veranderings in die vervalkoers van radioisotope wat van radiometriese datering gebruik maak, gevind is nie. Teoretiese berekenings van Bukowinski (1979:699) het aangetoon dat indien kalium-40 in die aarde se kors onder groot fisiese druk geplaas word, dit nie die elektronvangsproses beïnvloed nie; dus word die vervalkonstante van ${ }^{40} \mathrm{~K}$ nie verander deur die fisiese drukking van die korslaag nie. Ook die fisiese en chemiese prosesse wat meteoriete en rotse van die maan en aarde beïnvloed, soos druk, temperatuur swaartekrag, magnetisme en elektriese velde, het ook geen effek op die radioaktiewe vervalkonstantes van die radiogeniese isotope wat gebruik word om die ouderdom van gesteentes en fossiele te bepaal nie.

\subsubsection{Die beginsel van die werking van die klokke van radioaktiewe isotope}

In sy eenvoudigste vorm berus radiometriese datering op die ophoping in tyd van 'n dogterisotoop wat geskep word deur die radioaktiewe verval van 'n bepaalde hoeveelheid van die moeder in 'n geslote stelsel. 'n Geslote stelsel is waar materie nie na binne kom of mag uitgaan nie. Vergelyking (1) of (2) kan dan gebruik word, afhangend van die aanvanklike teenwoordigheid van die dogterisotoop al dan nie. In beginsel word die ouderdom van die gesteente vasgestel deur die hoeveelheid moeder- en dogterisotope teenwoordig in 'n enkele monster vas te stel vir enige van die vervalskemas in Tabel 1. In die praktyk verhoed die teenwoordigheid van 'n onbekende hoeveelheid van die aanvanklike dogterisotope egter die gebruik van so 'n eenvoudige metode. 'n Belangrike uitsondering is die moeder- en dogterpaar $\left({ }^{40} \mathrm{~K}\right.$ en $\left.{ }^{40} \mathrm{Ar}\right)$, asook spesiale en uitsonderlike ander voorbeelde. Hierdie "aanvanklike dogter"probleem is egter opgelos deur die toepassing van die isochroonmetode wat in 1961 deur 'n Suid-Afrikaner, L.O. Nicolaysen, van die Universiteit van die Witwatersrand uitgevind is. As voorbeeld hiervan word die ${ }^{40} \mathrm{~K}$ - en ${ }^{40} \mathrm{Ar}$-metode van naderby beskou.

\subsubsection{Die ${ }^{40} \mathrm{~K} /{ }^{40} \mathrm{Ar}$-dateringsmetode}

Hierdie metode is gebaseer op die verval van ${ }^{40} \mathrm{~K}$ na ${ }^{40} \mathrm{Ar}$ en is aanvanklik deur die meeste paleoantropoloë en geochronoloë gebruik. Onlangs is dit egter vervang deur die ${ }^{39} \mathrm{Ar} /{ }^{40} \mathrm{Ar}$-metode omdat dit noukeriger is. ' $n$ Interessante aspek van die radioaktiwiteit van ${ }^{40} \mathrm{~K}$ is dat hierdie moederisotoop verval deur twee maniere: elektronvangs na ${ }^{40} \mathrm{Ar}$ en deur $\beta$-uitstraling na ${ }^{40} \mathrm{Ca}$. Die verhouding van ${ }^{40} \mathrm{~K}$-atome wat verval na ${ }^{40} \mathrm{Ar}$-atome tot die verval na ${ }^{40} \mathrm{Ca}$ is 0,117 (vgl. Figuur 1). Dit word die vurkverhouding genoem. Omdat 
${ }^{40} \mathrm{Ca}$ die volopste $(97 \%)$ radioisotoop van $\mathrm{Ca}$ is en ook omdat $\mathrm{Ca}$ volop en orals in minerale voorkom, is dit nie moontlik om die hoeveelheid ${ }^{40} \mathrm{Ca}$ aanvanklik teenwoordig, te bepaal nie. Daarom word die ${ }^{40} \mathrm{~K} /{ }^{40} \mathrm{Ca}$-metode selde gebruik. Volledigheidshalwe kan genoem word dat van al drie die kaliumisotope wat in die natuur voorkom, ${ }^{39} \mathrm{~K}$ se voorkoms $93,26 \%,{ }^{40} \mathrm{~K}$ (die enigste radioisotoop) $0,117 \%$ en ${ }^{41} \mathrm{~K} 6,73 \%$ is.

\section{Figuur 1}

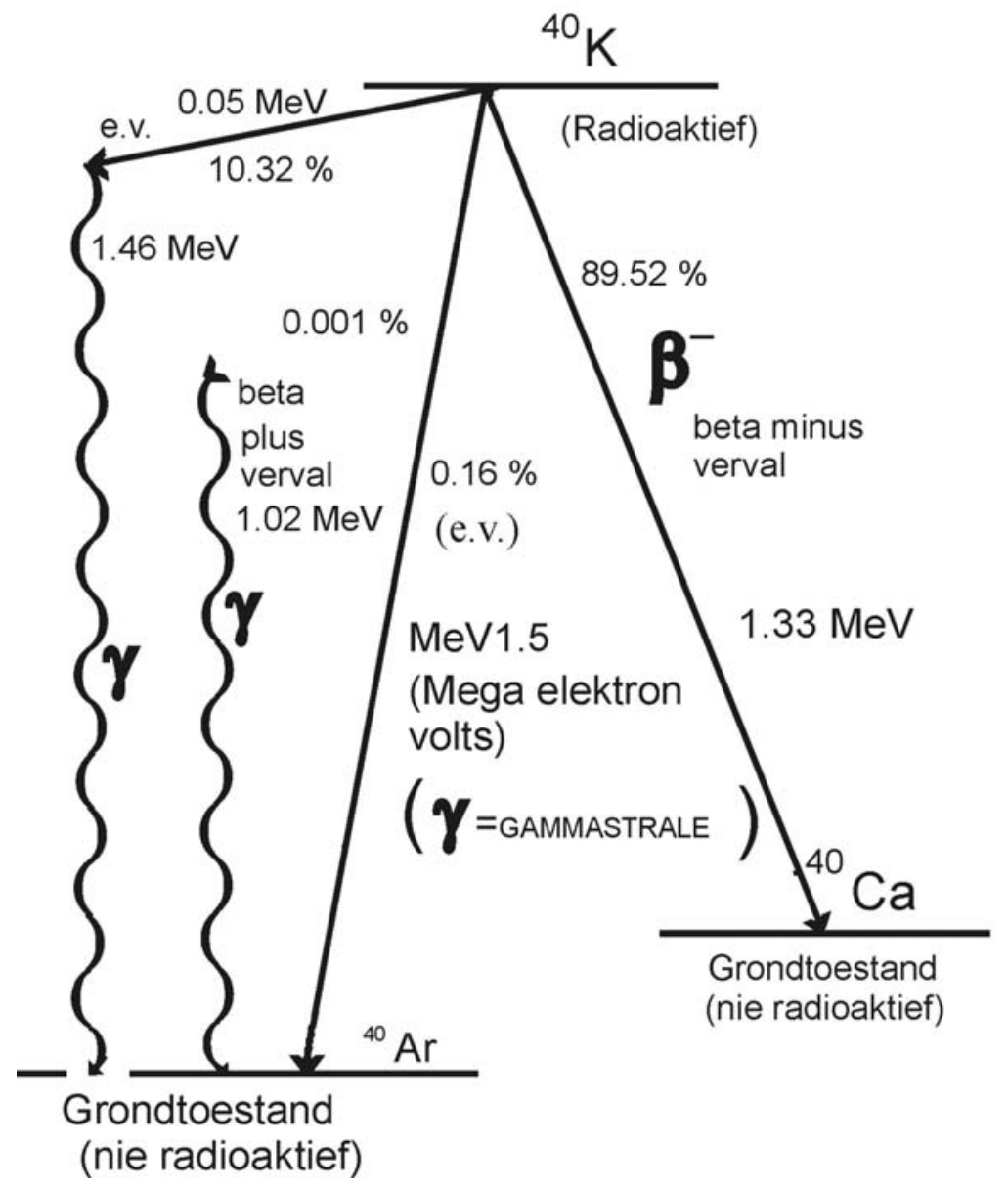

Die K-Ar-metode is die enigste vervalskema wat gebruik kan word met geen probleme vir die aanvanklike teenwoordigheid van die dogterisotoop nie. Dit is omdat ${ }^{40} \mathrm{Ar}$ ' $\mathrm{n}$ edel- of inerte gas is en nie chemies met ander elemente bind nie. As 'n gas ontsnap Ar ook maklik uit minerale en gesteentes indien dit verhit word. As die gesteente in 'n gesmelte toestand is, word die ${ }^{40} \mathrm{Ar}$ wat deur verval gevorm word, afgegee uit die vloeibare gesteente soos lawas. Nadat die gesteente gestol en afgekoel het, word die radiogeniese ${ }^{40} \mathrm{Ar}$ in die kristalstruktuur van die mineraal vasgehou. Dit akkumuleer met die verloop van tyd. Indien die gesteente later verhit of gesmelt 
word, kan 'n gedeelte of alles ontsnap, afhangend van die temperatuur wat toegepas word. $\mathrm{Na}$ afkoelng is die $\mathrm{K}-\mathrm{Ar}$-klok weer op "nul tyd" gestel. Dalrymple en Lanphere (1969:124) bewys dat by resente vloeiende lawa na afkoeling, nie 'n oormaat ${ }^{40} \mathrm{Ar}$ (aanvanklike ${ }^{40} \mathrm{Ar}$ plus ${ }^{40} \mathrm{Ar}$ ) voorkom nie.

'n Ander rede waarom die K-Ar-metode vir geoloë en paleoantropoloë so bruikbaar is, is die feit dat kalium baie algemeen in gesteentes voorkom en ook die hoofelement by 'n paar minerale is. Hoewel ${ }^{40} \mathrm{~K}$ die mins volopste isotoop van die drie kaliumisotope is, kom dit voor in meetbare hoeveelhede in die meeste gesteentes.

' $n$ Derde voordeel van die K-Ar-metode is die byna ideale halveertyd van ${ }^{40} \mathrm{~K}$, naamlik 1,25 miljard (of $\mathrm{Gj}$ ) jaar. Hierdie halveertyd is lank genoeg sodat die klok steeds loop in 'n gesteente wat $4,5 \mathrm{Gj}$ gelede gevorm is. Dit beteken dat die hoeveelheid van die moeder nog nie te klein geword het in gesteentes wat die oudste op aarde of die sonnestelsel is nie. Dié metode kan ook gesteentes meet wat so jonk as 50000 jaar is.

Omdat nuwe gestolde gesteentes nie aanvanklik ${ }^{40} \mathrm{Ar}$ bevat nie, kan Vergelyking 2 gebruik word vir hierdie metode. Maar dit moet gemodifiseer word om die vurkverval van $40 \mathrm{~K}$ in ag te neem:

$$
t=\frac{1}{Y_{e c}+\gamma_{\beta}^{-}} \frac{\log _{e}}{40 K} \quad \frac{\left.Y_{e c}+Y_{\beta^{-}}+1\right)}{Y_{e c}} \quad \text { (Vergelyking (3)) }
$$

waar $Y_{e c}$ en $\gamma_{\beta}{ }^{-}$die vervalkonstantes van e.c.(elektronvangs) en $\beta^{-}$verval respektiewelik is. Hierdie modifikasie gebruik slegs die konstantes en is geensins ' $n$ verandering in die fundamentele aard van die ouderdomsvergelyking nie. Wanneer die waardes van die vervalkonstantes van Tabel 1 in Vergelyking 3 gebruik word, is die K-Ar ouderdomvergelyking:

$$
\mathrm{t}=1,804 \times 10^{9} \log _{e}\left(\underline{9,54} \frac{40}{40} \frac{\mathrm{Ar}+1}{\mathrm{~K}}\right)
$$

waar $t$ in jare is.

Dus hoe meer ${ }^{40} \mathrm{Ar}$ in die gesteente teenwoordig is, hoe langer het die klok getik. Hoe meer ${ }^{40} \mathrm{Ar}$ in die gesteente is, hoe ouer is die gesteente.

Gedurende die analise moet 'n korreksie aangebring word vir die atmosferiese argongas wat teenwoordig is by die meeste minerale en in die eksperimentele apparaat. Die persentasie $\operatorname{Ar}\left({ }^{36} \mathrm{Ar},{ }^{38} \mathrm{Ar}\right.$, 
${ }^{40} \mathrm{Ar}$ ) in die atmosfeer is $0,93 \%$. Die korreksie kan aangebring word deur die hoeveelheid ${ }^{36} \mathrm{Ar}$ in die monster wat gedateer moet word te meet. Omdat die isotopiese samestelling van atmosferiese $\operatorname{Ar}\left({ }^{36} \mathrm{Ar}=\right.$ $0,337 \% ;{ }^{38} \mathrm{Ar}=0,063 \% ;{ }^{40} \mathrm{Ar}=99,60 \%$ ) presies bekend is, kan met die korreksiefaktor van ${ }^{36} \mathrm{Ar}$ die hoeveelheid ${ }^{40} \mathrm{Ar}$ in die atmosfeer bereken word en in Vergelyking (4) daarvan afgetrek word; wat oorbly is slegs radiogeniese ${ }^{40} \mathrm{Ar}$. Die korreksie kan baie noukeurig gemaak word, maar het in elk geval nie 'n noemenswaardige effek op die berekende ouderdom nie, mits die atmosferiese Ar nie 'n baie groot persentasie van die totaal uitmaak nie.

Soos met die meeste radiometriese metodes die geval is, werk die $\mathrm{K}-\mathrm{Ar}$-metode nie met al die tipes gesteentes nie. Geoloë het met die tyd geleer watter gesteentes en minerale as geslote stelsels reageer asook by watter geologiese toestande. Die K-Ar-tydklok werk baie goed vir stollingsgesteentes wat nie weer verhit is na vorming nie. Omdat hierdie metode gevoelig is vir hitte wat die tydklok weer na nul terugsit, is dit nie geskik vir die ouderdomsbepaling van meteoriete, maangesteentes, asook die oudste gesteentes op aarde nie. Die ${ }^{40} \mathrm{Ar} /{ }^{39} \mathrm{Ar}$-metode, ook bekend as die enkel-kristal-lasersmelt-Ar-Ar-datering meet die verhouding van ${ }^{40} \mathrm{Ar}$ tot ${ }^{39} \mathrm{Ar}$ in 'n kunsmatige radioisotoop wat in 'n kernreaktor geskep word van stabiele ${ }^{39}$ kalium. Die ${ }^{39} \mathrm{Ar}$ dien as maatstaaf of aanwyser van die hoeveelheid ${ }^{39} \mathrm{~K}$. Hierdie moderne metode oorkom meeste van die probleme wat met verdere verhittingsperiodes, nadat die gesteente gestol het, in verband staan. Tans is dit die aangewese metode om die ouderdom van gesteentes te bepaal waarin hominied-fossiele gevind is. Die ${ }^{39} \mathrm{Ar}$ wat vir hierdie metode gebruik word, is afkomstig van ${ }^{39} \mathrm{~K}$ wat met neutrone in 'n kernreaktor gemaak word. Van die verskillende dateringslaboratoriums in die wêreld is die Departement van Grondwetenskappe, Australiese Nasionale Universiteit, Canberra, ACT 0200, Australië, die leidinggewende dateringsinstansie (McDougall \& Harrison, 1988:12), waar die ${ }^{40} \mathrm{Ar} /{ }^{39} \mathrm{Ar}$ hoofsaaklik gebruik word.

As voorbeeld word die stappe bespreek in die ouderdomsdatering van die viermiljoen oue hominied, Australopithecus anamensis van Kenia, wat deur Leakey et al. (1995:567) beskryf is.

Die fossieldele van hierdie hominied wat by Alliabaai en Kanapoi verkry is, bestaan uit 'n onderkaak, bo-kaak en die bo- en onderente van die skeenbeen (tibia). Hierdie dele is in twee identiese horisonne (lae), 1,3 km van mekaar gevind. Die horisonne bestaan uit tephra (= van vulkaniese oorsprong) en bevat bruin veranderde kleigesteentes, waarskynlik van vorige puimsteen $(=$ sedimente 
afkomstig van vulkaniese gesteentes). In die bruin veranderde kleigesteentes word veranderende klaste (= brokstukke) gevind wat $10 \mathrm{~mm}$ in deursnee is. Glaskomponente in hierdie veranderde klaste is verplaas deur klei en zeoliet-minerale. Wat oorgebly het, as reste, is populasie alkalie-veldspaatkristalle $\left(\mathrm{KAISi}_{3} \mathrm{O}_{8}\right)$ van tot $1 \mathrm{~mm}$ in deursnee. Hierdie kristalle is gebruik vir die ${ }^{40} \mathrm{Ar} /{ }^{39} \mathrm{Ar}$ ouderdomdatering.

\section{Figuur 2}

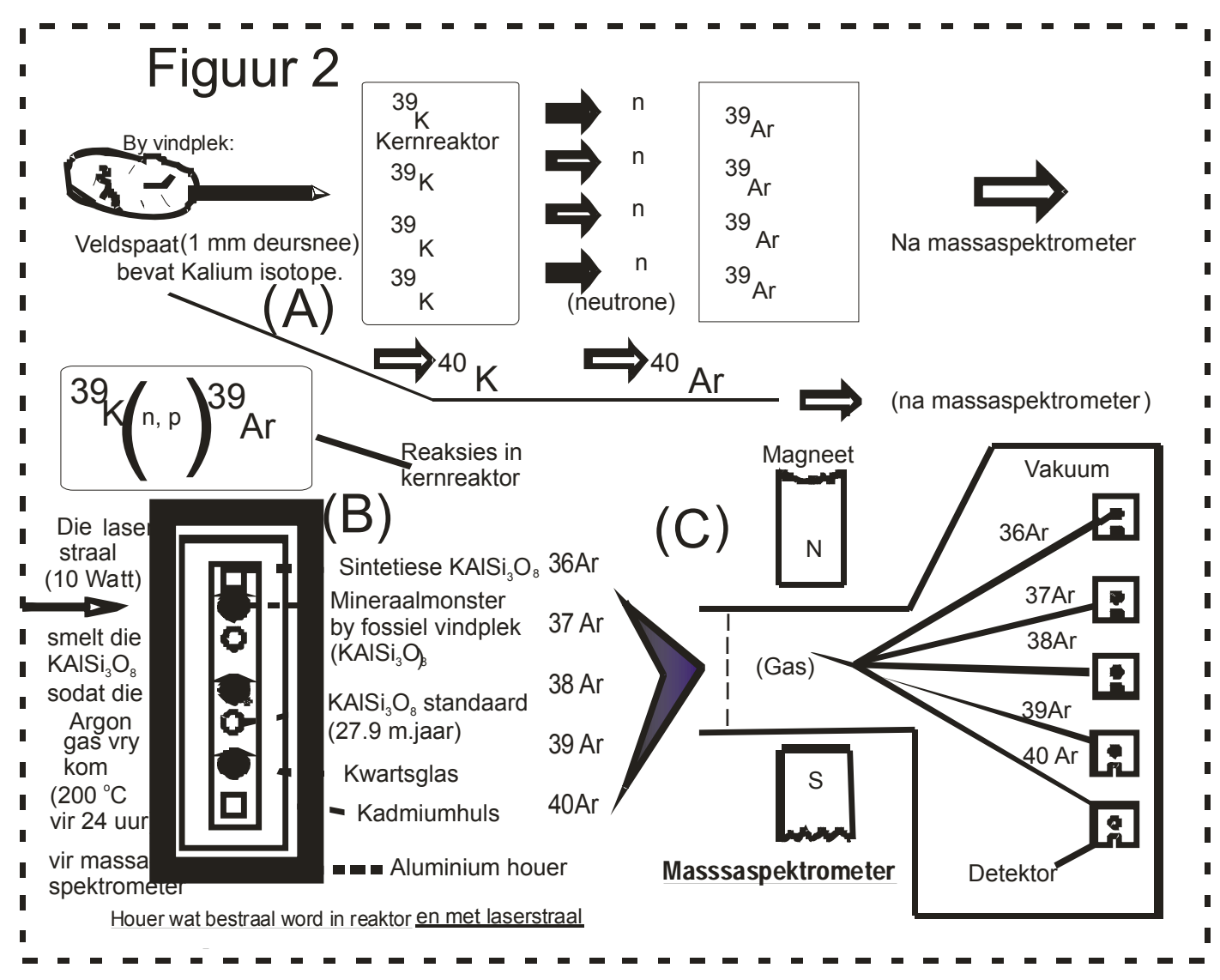

Vyf horisonne se ouderdom is bepaal met ten minste agt kristalle per horison. Die ouderdom het gevarieer van $3,912( \pm 0,037)$ miljoen jaar tot 4,165 ( \pm 0,033) miljoen jaar (Leakey et al.,1995). Verder is bykomend gebruik gemaak van die K/Ar-dateringsmetode om die ouderdom van die sedimentêre gesteentes vas te stel, wat afkomstig is van basaltgesteentes (= vulkanies) in die omgewing van Alliabaai. Daar is gevind dat die sedimentêre gesteentes tussen die interval van 4,17 tot 3,4 miljoen jaar gelede gevorm is. 
Die paleofauna van die vindplekke by Kanapoi en Alliabaai, Kenia, sluit ongeveer 30 soogdiersoorte en genera in, maar ook vis en ander akwatiese fossiele. Hierdie fauna kom ook by ander fossielvindplekke voor soos Laetoli wat 3,7 miljoen jaar oud is, soos deur die ${ }^{40} \mathrm{Ar} /{ }^{39} \mathrm{Ar}$-metode bepaal is.

In die praktyk kom die ${ }^{40} \mathrm{Ar} /{ }^{39} \mathrm{Ar}$-dateermetode daarop neer dat kristalle veldspaat wat vir datering gemeet word, in 'n buisie kwartsglas geplaas word, wat afgewissel word met veldspaatkristalle wat as standaard dien. Hierdie kristalle is afkomstig van die Visrafyn, Colorado, en is herhaaldelik deur die K/Ar- sowel as die ${ }^{40} \mathrm{Ar} /{ }^{39} \mathrm{Ar}$-metode getoets as 27,9 miljoen jaar oud. Vooraf is die ouderdom van die kristalle vanaf die Visrafyn deur vier laboratoriums van oor die hele werêld gemeet - die onderlinge verskil van ouderdom was minder as $2 \%$. Weerskante van die ry kristalle is ook sintetiese kaliumsilikaatglas geplaas (vgl. Figuur 2B). Die kwartsglasbuisie is in ' $n$ kadmiumhouer geplaas wat weer binnein 'n aluminiumhouer skuif vir bestraling deur neutrone in 'n kernreaktor (vgl. Figuur 2A). Na neutronbestraling word ${ }^{39} \mathrm{~K}$ omgesit na ${ }^{39} \mathrm{Ar}$ (vgl. Figuur 2A), terwyl kalsium-40 en chloor-37 respektiewelik na ${ }^{36} \mathrm{Ar}$, en ${ }^{38} \mathrm{Ar}$, verander word as dit in die monster aanwesig is. Korreksiefaktore moet dan vir hierdie argonisotope wat van kalsium en chloor verkry is, aangebring word. Die individuele kristalle word bestraal deur ' $n$ laserstraal van 10 watt sodat dit smelt (vgl. Figuur 2B). Argongasse wat op hierdie manier uit die veldspaatkristalle vrygestel word, word eers gesuiwer van ander gasse en dan in 'n gasbronmassaspektrometer vrygestel. Die ${ }^{36} \mathrm{Ar}$, ${ }^{37} \mathrm{Ar},{ }^{38} \mathrm{Ar},{ }^{39} \mathrm{Ar}$ en ${ }^{40} \mathrm{Ar}$ (almal gasse) word deur die massaspektrometer van mekaar geskei en die hoeveelhede van elke Arisotoop word vasgestel met tellers (vgl. Figuur 2C) en die data word rekenaarmatig gestoor.

Uit voorgaande kan afgelei word dat die vindplekke van fossieldele noukeurig bewaar en die posisies presies aangetoon moet word. Dit moet byvoorbeeld bekend wees met watter mineraal en afsetting die fossielvonds bedek en omhul was. Dit word gedoen om later ander dateringsmetodes en geassosieerde fauna te gebruik as die eerste metingtipes nie voldoende is nie. Tans het die delfplekke van die paleoantropoloë 'n "driedimensionele" aansig wat met transsekte, penne en kabels in stand gehou word. As 'n fonds gevind word, moet die herwinningsproses stap vir stap verfilm word. Dit verhoed dat vervalsings met die ontdekte eksemplare gepleeg word, soos wat dit die geval was met die Piltdown-mens. Hierdie vervalsing het plaasgevind aan die begin van die 20ste eeu en dit het die 
paleoantropologie as jong wetenskap baie skade berokken. Hierdie vervalsing is na veertig jaar blootgelê met die hulp van moderne dateringsmetodes en goeie opvolg-paleoantropologiese navorsing.

\subsubsection{Die U-Th-Pb-metode}

Hierdie metode is gebaseer op die radioaktiviteit van ${ }^{238} U,{ }^{235} U$ en ${ }^{232} \mathrm{Th}$, wat almal verval na verskillende isotope van $\mathrm{Pb}$. Ten spyte van probleme wat veroorsaak word deur die intermediêre dogterprodukte wat verskyn, kan die verval van ${ }^{238} \mathrm{U}$ na ${ }^{206} \mathrm{~Pb},{ }^{235} \mathrm{U}$ na ${ }^{207} \mathrm{~Pb}$ en ${ }^{232} \mathrm{Th}$ na ${ }^{208} \mathrm{~Pb}$ as een-stap-verval beskou word.

Die mineraal, zirkonium, is nie in groot hoeveelhede in die aardkors teenwoordig nie, maar besit relatief baie $U$ en Th en kom by die meeste soorte gesteentes voor. Verder bevat hierdie mineraal uiters min aanvanklike $\mathrm{Pb}$, wat die dateringsproses vergemaklik. 'n Ander probleem met die U-Pb- en Th-Pb-vervalprosesse is dat die stabiele $\mathrm{Pb}$ wat gevorm word maklik met tyd uit die mineraal kan ontsnap, want $\mathrm{Pb}$ is ' $\mathrm{n}$ "vlugtige" metaal. Daarom is gebruik gemaak van die verhouding van ${ }^{207} \mathrm{~Pb}$ tot ${ }^{206} \mathrm{~Pb}(=137,88)$ om vir die verdampingseffek te korrigeer.

Die vergelyking wat gebruik word om die berekenings ná die metings te doen, is in beginsel dieselfde as wat vir die K-Ar-metode gebruik word. Die U-Pb-metode, tesame met die toepassings van die isochroonbeginsel (Dalrymple, 1991:109) word gebruik om die ouderdom van maanrotse, meteoriete en aardgesteentes wat baie oud is, vas te stel. Die verhouding van 137,88 van ${ }^{207} \mathrm{~Pb}$ tot ${ }^{206} \mathrm{~Pb}$ afkomstig van die aarde se rotse, is dieselfde as in meteoriete en maanrotse. Die ouderdomreikwydte is tussen 0,10 en meer as 4 biljoen jaar (Dalrymple, 1991:119).

\subsubsection{Radiokalsium}

Soos ${ }^{14} \mathrm{C}$ word ${ }^{41} \mathrm{Ca}$ gevorm deur kosmiese strale wat termiese neutrone in die kern van ${ }^{40} \mathrm{Ca}$ skiet. Hierdie kernreaksie $\left({ }^{40} \mathrm{Ca}\right.$ $\left.(n, y)^{41} \mathrm{Ca}\right)$ vind nie in die atmosfeer plaas nie, maar in die boonste meterdikte van die grond regoor die aardbol. Na produksie meng die ${ }^{41} \mathrm{Ca}$ met ander natuurlik voorkomende kalsium. Radioaktiewe ${ }^{41} \mathrm{Ca}$ word, net soos die ander Ca-isotope, deur plante uit die grond en ook deur diere opgeneem. Die ${ }^{41} \mathrm{Ca}$ beland uiteindelik in beenminerale. Die ${ }^{41} \mathrm{Ca} /{ }^{40} \mathrm{Ca}$-verhouding sal by die lewende dier dieselfde bly. Anders as by ${ }^{14} \mathrm{C}$ waar die tyd $=0$, as die dier of plant doodgaan, begin die tydklok vir ${ }^{41} \mathrm{Ca}$ "tik" eers as die dier ten minste drie meters onder die grond of in 'n diep grot lê. By hierdie diepte 
vind volledige afskerming van termiese neutrone, gevorm deur kosmiese strale plaas, sodat hierdie neutrone nie die ${ }^{40} \mathrm{Ca}$ kan bereik nie. Slegs die verval van ${ }^{41} \mathrm{Ca}$ na ${ }^{41} \mathrm{~K}$, deur elektronvangs $\left[{ }^{41} \mathrm{Ca}(\mathrm{e}, \mathrm{v})\right]$ vind plaas met die afgee van 'n neutrino (Taylor, 1987:327). Die verhouding van ${ }^{14} \mathrm{Ca}$ tot ${ }^{40} \mathrm{Ca}$ en die halveertyd van 100000 jaar vir ${ }^{41} \mathrm{Ca}$ word gebruik om die ouderdom van veral bene en fossielbene in diep grotte en in diep afsettings te bepaal. Die ouderdomreikwydte is tussen 1000 jaar en een miljoen jaar, wat dit baie geskik maak vir die ouderdomsdatering van hominiede. Hierdie metode is egter nog in die eksperimentele stadium van ontwikkeling.

\subsubsection{Radiokoolstof- of koolstof-14-metode}

Een van die belangrikste absolute dateringsmetodes is die radiokoolstofmetode wat ongeveer 60 jaar gelede uitgevind en as 'n eerste poging toegepas is om die ouderdom van 'n stukkie akasiahout, afkomstig van Saqqara, die oudste trapvormige piramied in Egipte, vas te stel. Radiokoolstofdatering kan direk toegepas word op been of op enige ander organiese materiaal wat koolstof bevat. Ouderdom kan vasgestel word deur die hoeveelheid koolstof-12 te meet - koolstof-12 is die oorheersende vorm van natuurlike koolstof in die organiese monster. Vervolgens word gemeet hoeveel koolstof-14, wat radioaktief is, in die monster aanwesig was toe die voorwerp (plant of dier) nog gelewe het (vgl. Figuur 3).

Omdat koolstof-14 na stikstof-14 verval met 'n konstante tempo, kan, met die kennis van die huidige hoeveelheid koolstof-14 in 'n houtmonster, die ouderdom van die aksiahout bereken word as die oorblywende ${ }^{14} \mathrm{C}$ in die Saqqarahout gemeet word. Die akasia van Saqqara het getoon dat die piramied 4600 jaar gelede gebou is. Die radioaktiewe koolstofmetode werk egter net vir relatief jong organiese voorwerpe, omdat die halfveertyd van koolstof-14 slegs $5730( \pm 112)$ jaar is. Omdat 'n monster van die koolstof-14 na elke 5730 jaar met die helfte verminder, verminder die aantal koolstof14-atome na 'n tyd van 4000 jaar tot sulke klein hoeveelhede wat dit onbetroubaar maak om dit met sintillasietellers te meet. 'n Nuwe metode om die koolstof-12 en -14 noukeuriger vas te stel word tans gedoen deur die sogenaamde versnelde massaspektrometer te gebruik. Hiervolgens kan die tydspan van die koolstof-14dateringstegniek uitgebrei word na 75000 jaar. Die nuwe tegniek het die bykomende voordeel dat slegs een duisendste van 'n gram materiaal nodig is om die fossielvoorwerp te dateer. Op hierdie wyse was dit moontlik om die ouderdom van kosbare grotskilderye in Frankryk te bepaal met een milligram verf wat van die skildery geneem is. Dit het geblyk dat die tekeninge ouer as 20000 jaar is. 
Figuur 3: Diagram om die vorming van koolstof-14 uit stikstof voor te stel: verspreiding en verval na vorming

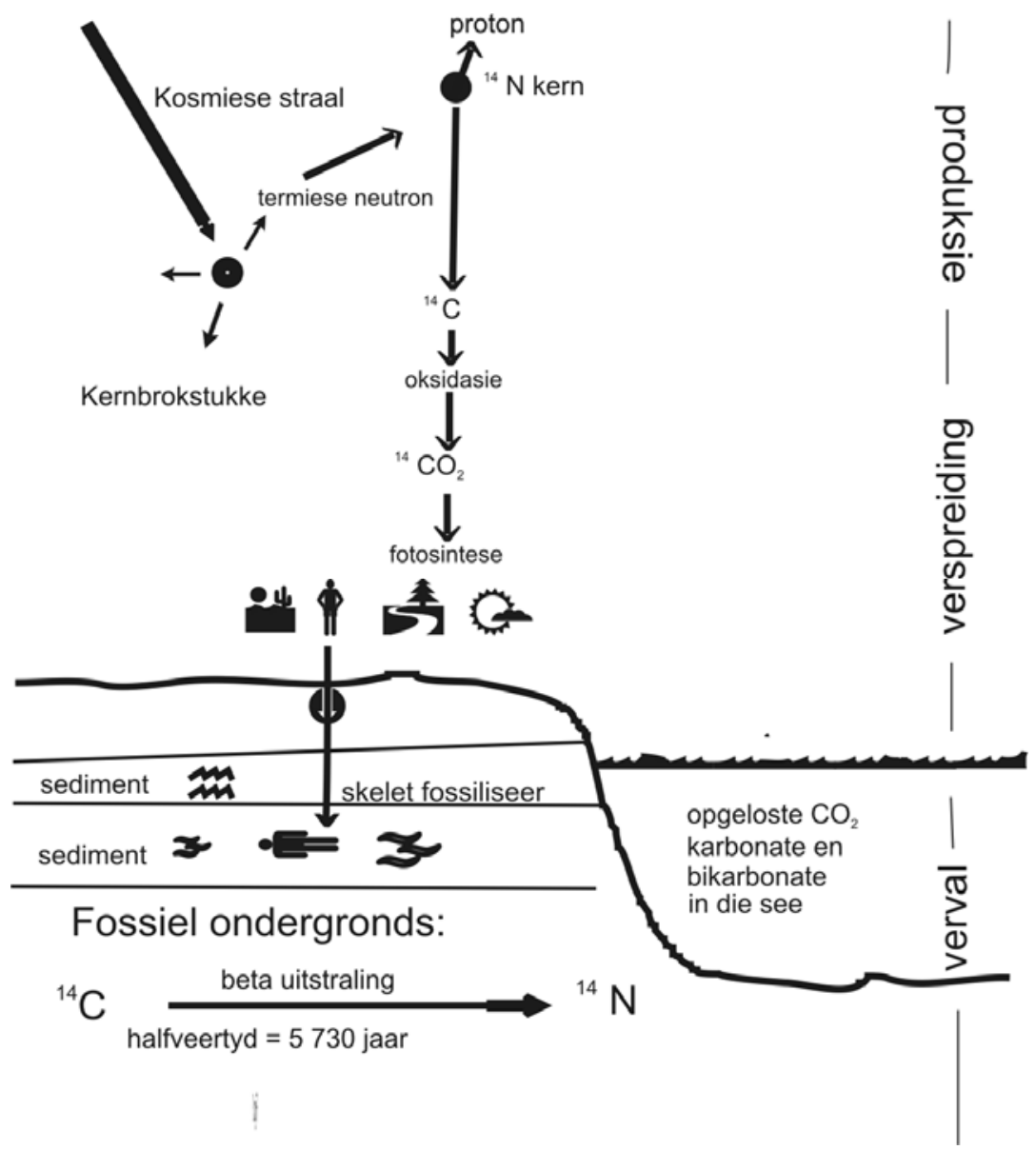

\section{Ander absolute dateringsmetodes}

\subsection{Geomagnetisme}

As gesmelte vulkaniese gesteentes afkoel en stol, word die magnetiese minerale in die stolsel gemagnetiseer in die rigting van die aarde se magneetveld. Hierdie magnetisme word behou en dien as 'n permanente magneetgeheue van die rigting van die aarde se magneetveld van dié bepaalde gesteente op dié bepaalde plek of horison, tydens die tyd van stolling. Dit beteken dat die aarde se magneetveld twee stabiele toestande voorstel: dit kan slegs na die Noordpool wys, soos ons dit vandag ken, of na die Suidpool. Die omkering is 180 grade en niks tussenin nie (vgl. Figuur 4). In die verlede het hierdie twee stabiele toestande van die magneetveld telkemale gewissel van 'n noordelike rigting na 'n suidelike rigting en omgekeerd. Op die oomblik bestaan daar geen verklaring hoe 
hierdie omkering plaasvind nie en die meganisme van die omkering is ook onbekend.

Dit gebeur ook dat die magnetisme van vulkaniese gesteentes voorkom in dieselfde gesteentes wat "atoomklokke" huisves, soos die K-Argonklok. Dit beteken dat die K-Ar-klok op presies dieselfde tyd begin "tik" as wanneer die magnetiese rigting in die lawastolsel vasgelê is. Dit het tot gevolg dat wetenskaplikes met byvoorbeeld die K-Argonklok, tesame met die geomagnetiese omdraaiings, 'n tydskaal van die afgelope 4,5 miljoen jaar kon opgestel, waarin nie minder nie as 24 omdraaiings van die aarde se magneetveld voorkom (Cox et al., 1973:326).

Die duur van 'n omdraaiing kan so kort as 100 duisend jaar wees, maar is gemiddeld 500-700 duisend jaar uitmekaar. Die duur van die polariteitsoorskakeling van 'n omdraaiing is minder as 5 duisend jaar en dien, geologies gesien, as skerp tydmerkers van die aarde se geskiedenis. So is byvoorbeeld gevind dat 1,9 miljoen jaar gelede 'n magnetiese omdraaiing plaasgevind het in die lawa by die bekende Olduvai-rafyn wat ryk is aan homoniede en ander fossiele. Hierdie omdraaiing het sowat 100 duisend jaar geduur voordat dit skielik omgedraai het. Ander dateringsmetodes soos ${ }^{39} \mathrm{Ar} /{ }^{40} \mathrm{Ar}$ het bevestig dat die lawalaag 1,9 miljoen jaar oud is.

Fyn sedimentêre deeltjies van yster- en titaniumoksiedes word ook in die aarde se magneetveld gemagnetiseer gedurende hulle afwaartse beweging in stil water. Die omdraaiingsperiodes in sedimente stem ook presies ooreen met die magnetiese omdraaiings wat in vulkaniese gesteentes gemeet is.

Die geheue-elemente in gesteentes bestaan uit magnetiese domeine. Dit is klein deeltjies waarvan die magnetisme uniform is en word saamgestel uit verskeie yster- en titaniumoksiedes. By temperature van meer as $1200^{\circ} \mathrm{C}$ is die yster en titanium oksiedes nie-magneties nie, maar word magneties as dit afgekoel word verby die Curie-temperatuur, wat by vulkaniese gesteentes tussen 680 en 200 grade Celsius is, afhangende van die chemiese samestelling van die mineraal.

Die Curie-temperature is baie laer as die 1000 grade Celsius waarby gesteentes gewoonlik kritalliseer. Dit beteken dat gesteentes nie gemagnetiseer word deur die fisiese rotasie en orientasie van die aarde se magneetveld van vorige gemagnetiseerde mineraalkorrels in die gesmelte lawa nie. Aan die onderkant van die Curietemperatuur begin die domeine van yster- en titaniumoksiedes van 
'n sagte na 'n harde magnetisme oorgaan (Cox et al., 1973:326) wat vergelyk kan word met die magnetisme van 'n mensgemaakte permanente magneet.

In die praktyk kom dit daarop neer dat van 'n gestolde gesteente of sediment 'n kern van die onversteurde lawa of sediment met 'n hol diamantboor uitgesny word. Elke kern se orientasie ten opsigte van die horisontale vlak en die egte noordelike rigting word noukerig opgeteken (vgl. Figuur 4). In die laboratorium word die magnetiese vektor of afwyking van elke kernmonster met 'n magnetometer bepaal. In beginsel bestaan 'n magnetometer uit 'n roterende staaf. Aan die een punt van die staaf word die kernmonster vasgemaak. Aan die ander punt word 'n toets- of ykmagneet geheg wat dieselfde magnetiese rigting as die huidige magneetveld het. Die twee staafpunte draai bokant 'n koperdraadklos wat dan twee elektriese seine uitstuur wat op 'n ossilloskoop waargeneem kan word as 'n sinusgolf in volteenhede. Die faseverskil van die golf tussen die ykmonster en kernmonster dui die omkering van Suid na Noord aan.

Geomagnetisme kan egter nie alleen gebruik word as dateringsmetode van gesteentes en fossiele nie. As 'n sedimentêre laag of stollingsgesteente se magneetveld byvoorbeeld Suid wys, kan dit een van 13 suidelike-rigtingomkerings in 4,5 miljoen jaar wees (Cox, 1973:325). As die omdraaiingsperiode in 'n bepaalde karakteristieke sediment of stollingsgesteente voorkom waar die fossiel is, en die ouderdom van die sediment is radiogenies bekend, kan paleoantropoloë hierdie kennis gebruik om 'n afgeleide absolute datering vir ander soortgelyke sediment of horison te doen sonder die gebruik van duur en tydrowende radiometriese metodes. 
Figuur 4

\section{Monsterkerne vir paleomagnetiese studies}

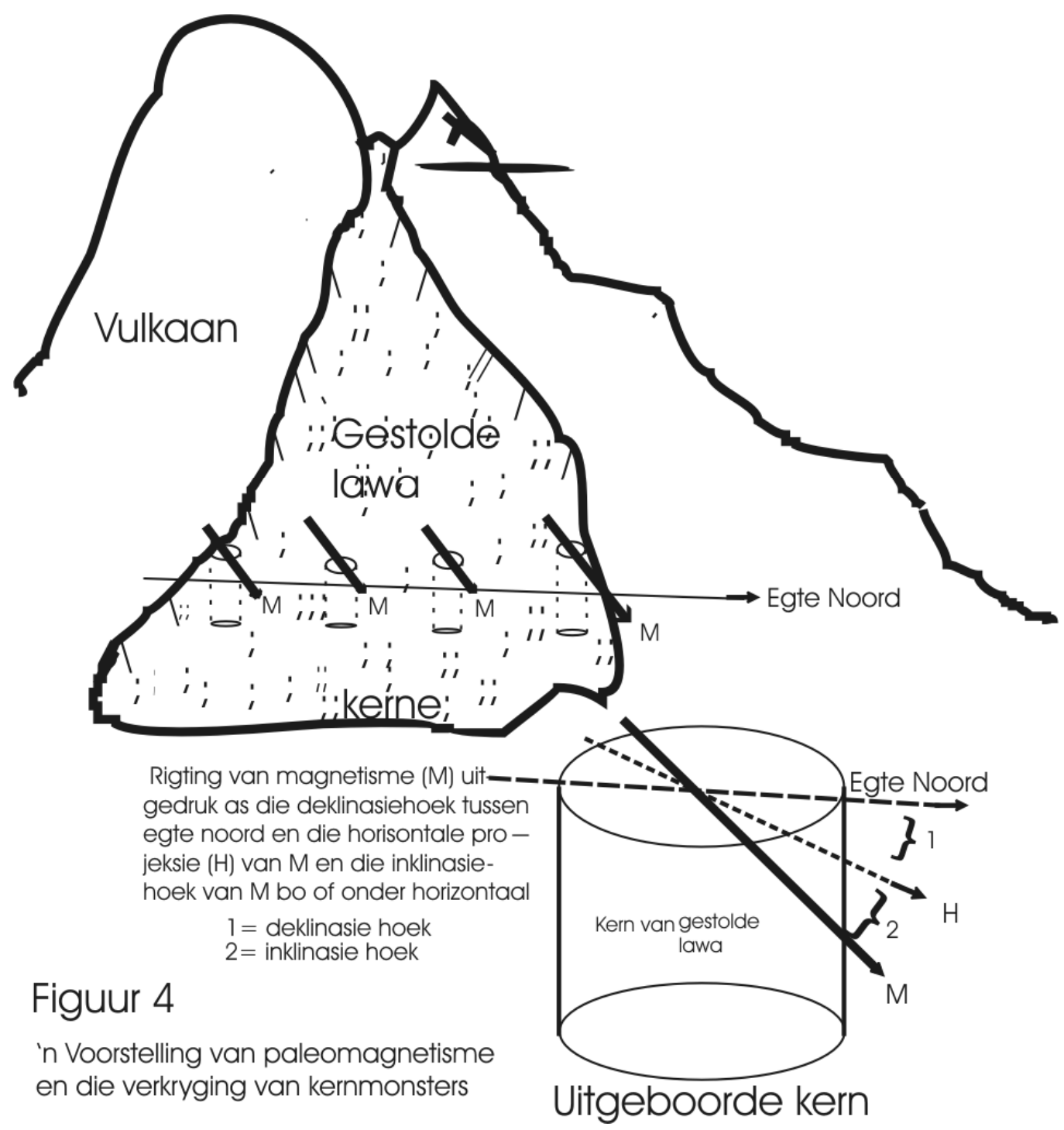

\subsection{Aminosure}

Die aminosure wat deur organismes geproduseer word, is, opties gesien, linksdraaiend (L). As 'n organisme doodgaan en begrawe word verander die L-aminosure geleidelik deur die proses van rasemisasie na die $D$ of regsdraaiende aminosuur. Die spoed van hierdie proses is afhanklik van temperatuur. Uiteindelik word ' $n$ opties onaktiewe mengsel gevorm. Hierdie dateringsmetode word toegepas op fossiele, mariene sedimente, argaïese skilderstukke, 
grond- en pedokrete. Die ouderdomsreikwydte met hierdie metode vir bene is tussen 50000 en 100000 jaar. Die metode is beperkend, omdat verhoogde temperature die rasemisasieproses versnel. As die monster se temperatuur konstant laag gehou word, soos wat die geval is met sedimente afkomstig van diepseegebiede of van veenvleiomgewings is dit 'n geskikte dateringsmetode.

\subsection{Opties-gestimuleerde luminesensie (OSL)}

Die OSL-metode is gebaseer op die feit dat alfa- beta- en gammastraling, wat ontstaan van klein hoeveelhede radioaktiewe stowwe, byvoorbeeld kalium-40 in die grond, elektrone in die mineraal verplaas. Hierdie elektrone word vasgevang in die kristalrooster. Dit kan vir meer as 'n miljoen jaar daar vertoef mits die materiaal nie bokant $300{ }^{\circ} \mathrm{C}$ verhit word nie. Die kumulatiewe aantal elektrone wat vasgevang word is dus 'n funksie van tyd. As die mineraal fyngemaal en dan verhit word, kom die elektrone vry en reageer met sekere plekke in die kristal om fotone of lig te vorm. Die fotone word getel met die hulp van 'n sintillasieteller. Die ouderdomsreikwydte is van 3500 tot 10 miloen jaar (Partridge et al., 1984:395).

\subsection{Elektronspinresonansie( ESR)}

Soos die OSL-metode maak ESR ook gebruik van die akkumulasie van vasgevangde elektrone wat deur natuurlike radioaktiewe straling in die kristalstruktuur beland. ESR se voordeel bo OSL is dat dit nie nodig is om die monster te verhit nie. Die ESR is gebaseer op die beginsel dat verplaasde elektrone vasgevang word as enkelelektrone in plaas van in pare, wat die normale toestand voorstel. Die enkele elektron produseer magnetiese momente wat deur 'n ESR-spektrometer gemeet word. Die meeste van die ander beperkings van OSL is ook van toepassing op ESR en sy ouderdomsreikwydte is vanaf 3500 tot 10000 jaar (Partridge et al., 1984:396)

\subsection{Datering met behulp van ${ }^{238}$ uraan se splytingspore}

'n Splytingspoor is 'n gebied van intense beskadiging as 'n splytingsfragment deur 'n vastestof beweeg. Hoewel verskeie natuurlike voorkomende radioisotope spontane splyting ondergaan, het slegs ${ }^{238}$ uraan 'n splytingshalveertyd van $9,9 \times 10^{15}$ jaar, sodat dit 'n betekenisvolle aantal spore in 'n mineraal vorm tydens ' $n$ lang geologiese tydperk. As ${ }^{238}$ uraan se kern opbreek, word twee ligter kerne gevorm wat elkeen 'n sterk lading dra. Elke kern beweeg 180 
grade weg van mekaar en beïnvloed die elektronbalans van die atome in die kristalrooster van die mineraal sodat ' $n$ beskadigde spoor gevorm word.

Die spoor is ongeveer 1 mikrometer in breedte en tot 20 mikrometer in lengte en kan maklik met 'n elektronmikroskoop gesien en getel word. Omdat splyting met 'n konstante koers plaasvind, kan dit gebruik word om die mineraal se ouderdom vas te stel. Dit is egter nodig dat die hoeveelheid ${ }^{238}$ uraan in die mineraal eers vasgestel word. Die verhouding van die aantal gesplyte ${ }^{238}$ uraan en die ${ }^{238}$ uraan wat nog in die mineraal aanwesig is, word gebruik om die ouderdom te bepaal. Die ouderdomsreikwydte met hierdie metode is van 'n paar honderd duisend jaar tot meer as 1000 miljoen jaar (Naeser \& Naeser, 1984:87).

\section{Slotopmerking}

Van al die metodes wat gebruik word om die ouderdom van fossiele ouer as 1 miljoen jaar te bepaal, is die ${ }^{40} \mathrm{Ar} /{ }^{39} \mathrm{Ar}$ die noukeurigste en daarom word dit die meeste gebruik om hominiedfossiele se ouderdom te bepaal. Die ander tegnieke soos die U-Th-Pb-metode word hoofsaaklik gebruik om die ouderdom van die aarde vas te stel wat 4,5 biljoen jaar oud is.

'n Belangrike aspek van datering is dat dieselfde monsters na ander dateringslaboratoriums gestuur moet word om vas te stel of daar verskille is in die dateringsresultate tussen die laboratoriums. Deur die gebruik van tydklok-standaard soos die KAISiO3, afkomstig van 'n bepaalde plek in die Visrafyn, Colorado, VSA in die dateringsprosedure te plaas, is dit tans nie meer nodig om monsters na verskillende dateringslaboratoriums te stuur nie. Die koolstof-14metode, wat eintlik nie vir paleoantropologiese materiaal gebruik word nie, is slegs geskik vir die vasstelling van die ouderdom van antropologiese artefakte van organiese oorsprong minder as 70 duisend jaar oud.

Ten slotte word vertrou dat hierdie vereenvoudige inligting en figure oor redelike ingewikkelde begrippe en tegnieke om fossielouderdomme vas te stel, sal meehelp dat die gewone leser en Christengelowiges met hierdie wetenskaplike inligting sal kan verstaan dat die mensagtige fossiele in Afrika miljoene jaar oud is en nie slegs 'n paar duisend jaar nie. 


\section{Geraadpleegde bronne}

BUKOWINSKI, M.S.T. 1979. Theoretical estimate of compressional changes of decay constant of ${ }^{40} \mathrm{~K}$. Geophysical Research Letters, 6:697-699.

COX, A., DALRYMPLE, G.B., \& DOELL, R.D. 1973. Reversals of the earth's magnetic field.(In Cox, A., ed. Plate tectonics and geomagnetic reversals. San Francisco: Freeman. p. 188-206.)

DALRYMPLE, G.B. 1991. The age of the earth. Stanford: Stanford University Press.

DALRYMPLE, G.B. \& LANPHERE, M.A. 1969. Potassium-argon dating. San Fransisco: Freeman.

EMERY, G.T. 1972. Perturbation of nuclear decay rates. Annual Reviews of Nuclear Science, 22:165-202.

HOPKE, P.K. 1974. Extranuclear effects on nuclear decay rates. Journal of Chemical Education, 51:517-519.

JOHANSON, D. \& EDGAR, B. 1996. From lucy to language. Witwatersrand: Witwatersrand University Press.

LEAKEY, M.G., FEIBEL, C.S., MCDOUGALL, I. \& WALKER, A. 1995. New fourmillion-year-old hominid species from Kanapoi and Allia Bay, Kenya. Nature, 376:565-571.

MCDOUGALL, I. \& HARRISON, T.M. 1988. Geochronology and Thermochronology by the ${ }^{40} \mathrm{Ar} /{ }^{39} \mathrm{Ar}$ method. New York: Oxford University Press.

NAESER, N.D. \& NAESER, C.W. 1984. Fission-track dating. (In Mahaney, W.C., ed. Quaternary dating methods. New York: Elsevier. p. 87-100.)

PARTRIDGE, T.C., NETTERBERG, F., VOGEL, J.C. \& SELLSCHOP, J.P.F. 1984. Absolue dating methods for the Southern African Cainozoic. South African Journal of Science, 80:394- 400.

TAYLOR, R.E. 1987. Dating techniques in archaeology and paleoanthropology. Analytical Chemistry, 59:317A-331A.

WATSON, VIRGINIA. 1993. Composition of the Swartkrans bone accumulations, in terms of skeletal parts and animals represented. (In Brain, C.K., ed. Swartkrans: a cave's chronicle of early man. Pretoria: Transvaal Museum. p. 35-73.) (Transvaal Museum Monograph, no. 8.)

\section{Kernbegrippe:}

absolute ouderdomsdatering datering van hominiedfossiele radiometriese ouderdomsdatering relatiewe ouderdomsdatering

\section{Key concepts:}

absolute dating methods dating of hominid fossils radiometric dating methods relative dating methods 